\title{
PKM PENGARUH PELATIHAN FITNESS SISWA SMA NEGERI 3 TONDANO
}

\author{
Bacilius Sukadana \\ Universitas Negeri Manado \\ baciliussukadana@unima.ac.id \\ Ellen B. Lomboan \\ Universitas Negeri Manado
}

\section{PENDAHULUAN}

Fitness memerlukan kekuatan oto dan daya tahan otot memerlukan komponen kondisi fisik yang baik sehingga seseorang dapat berlatih sesuai dengan otot apa yang ingin ditingkatkan. Untuk dapat memiliki otot yang baik sudah tentu harus melalui pelatihan yang berulang-ulang dan sistematis kian hari menambah beban pelatihannya

\section{Prestasi olahraga dipengaruhi} oleh aspek-aspek antara lain : atlet, pelatih, dokter, lingkungan sekitar, program latihan, gizi (Makanan), model latihan, waktu istirahat yang cukup. Hal inilah yang perlu diperhatikan oleh pelatih ataupun guru olahraga untuk meningkatkan prestasi olahraga secara maksimal.

Setiap usaha untuk meningkatkan prestasi olahraga latihan fisik merupakan salah satu unsur yang sangat diperlukan.Walaupun telah memiliki teknik, mental yang baik tidak dilandasi dengan kondisi fisik merupakan salah satu unsur yang sangat diperlukan.walaupun telah memiliki teknik, mental yang baik tidak dilandasi dengan kondisi fisik yang prima maka sangat sulit mendapatkan prestasi yang diharapkan.Dalam prmainan bola basket memerlukan penguasaan teknik dasar yang baik serta program latihan yang tepat dan terprogram secara sistematis.

Kekuatan otot dan daya tahan otot sangat dibutuhkan dalam seluruh cabang olahraga selain tidak mengabaikan komponen kondisi fisik yang lainnya.Fitness

Berdasarkan pengamatan penulis bahwa siswa putra SMA Negeri 3 Tondano belum menguasai Fitness karena belum pernah mendapatkan pelatihan diharapkan kedepannya bisa memiliki pengetahuan dan kemampuan fitness yang baik setelah mendapatkan pelatihan.Pelatihan ini dapat berjalan dengan baik bahkan para siswa yang terlibat dalam pelatihan ini sangat antusias melaksanakan pelatihan. Hal ini dapat mendorong para siswa lebih giat dalam proses pembelajaran di sekolah. 


\section{METODE PELAKSANAAN}

\section{A. Realisasi Pemecahan masalah}

Kegiatan awal dilakukan meliputi:

a. Mengadakan kunjungan ke sekolah sekaligus membawa surat tugas melaksanakan pengabdian masyarakat ke sekolah

b. Menetapkan jadwal pelaksanaan pelatihan

c. Menyiapkan Materi pelatihan

d. Pelaksanaan Pelatihan

\section{B. Metode dan Teknik}

Metode yang digunakan dalam kegiatan pelatihan ini sudah direncanakan terlebih dahulu dan sesuai dengan metode yang biasanya digunakan di dalam aktivitas pelatihan. Adapun metode yang digunakan yaitu:

\section{Metode Konvensional}

Metode konvensional dilakukan pada awal pelatihan. Dimana siswa menerima informasi dan pengetahuan dari tim pelaksana. Narasumber menjelaskan dan menerangkan fitness yang tepat dan benar. Dalam Hal Pembebanan harus menggunakan Rumus 1 RM (Repetisi Maksimal) untuk menentukan beban awal individu agar tidak salah menentukan beban masing-masing individu. Salah satu contoh pembebanan di tes kemampuan individu dalam $1 \mathrm{RM}$ sampai tidak mampu mengangkat beban misalnya mampu mengangkat beban dalam 1 RM 20 kg ,Intensitas pelatihan $60 \%$ Jadi $60 / 100 \times 20$ $\mathrm{kg}=12 \mathrm{~kg}$ inilah beban awal anak-anak yang akan diberi pelatihan fitness pada setiap alat yang akan digunakan sesuai dengan peruntukannya.

\section{Metode Diskusi}

Metode Diskusi dilakukan pada tahap pertengahan, dimana narasumber memberikan arahan untuk membentuk beberapa kelompok diskusi, dan memberikan bahan diskusi mengenai fitness. Ketika siswa sudah mendapatkan bahan diskusi masing-masing, maka dibahas secara berkelompok dan diberikan waktu untuk dibahas secara umum, dengan memberikan pertanyaan dan jawaban.

3. Metode Demonstrasi di ruangan fitness

Metode akhir yang dilakukan adalah metode demonstrasi/ latihan langsung dari narasumber dan diikuti oleh siswa yang mengikuti pelatihan fitness sesuai dengan program yang diberikan

a Langkah-Langkah Kegiatan

Dalam kegiatan pelaksanaan pelatihan ini dianggap perlu sebagai acuan pelaksanaan kegiatan. Adapun langkah-langkah kegiatan yaitu :

1. Narasumber menjelaskan tentang teori teknik dasar fitness.

2. Menerangkan mengenai fitness yang benar serta cara individu menentukan beban awal pelatihan dengan menggunakan Rumus 1 RM (repetisi maksimal). 
3. Membentuk kelompok untuk memahami cara menentukan beban awal pelatihan.

4. Mengevaluasi pemahaman siswa dengan memberikan pertanyaan yang akan dijawab kelompok siswa yang sudah dibentuk.

5. Setelahh memantapkan pemahaman siswa mengenai fitness, dilanjutkan dengan metode demonstrasi.

6. Tim melakukan demonstrasi di ruang fitness dan siswa mengikutinya. Saat siswa mengikuti demonstrasi yang dibuat oleh tim, tim pelaksana membuat penilaian secara sistematis dan terstruktur untuk mendapatkan data atau nilai yang baik.

7. Latihan dilakukan secara rutin sampai mendapatkan nilai yang sesuai. Sementara latihan berlangsung, penilaian dilakukan secara terus menerus agar nilai yang diperoleh dapat dilihat sebagai acuan kemajuan yang diperoleh dalam latihan masing-masing siswa.

8. Apresiasi untuk siswa yang dianggap lolos dalam pelatihan dengan memberikan bukti berupa sertifikat atau penghargaan lainnya.

\section{HASIL DAN PEMBAHASAN}

\section{HASIL}

Kegiatan pengabdian masyarakat ini adalah suatu bentuk kegiatan pelatihan fitness yang diberikan untuk meningkatkan fisik seseorang dan pengetahuan siswa serta keterampilan siswa-siswa SMA Negeri
3 Tondano agar dapat menopang proses pembelajaran secara keseluruhan. Pelatihan ini dilaksanakan sebagai bentuk pertanggung jawaban pendidikan tinggi untuk mengembangkan IPTEK, dengan memiliki pengetahuan tentang fitness dengan baik maka prestasi cabang olahraga akan meningkat dan dapat menyiapkan atlet-atlet yang potensial bila dilatih dengan ilmiah.

Dengan mengikuti pelatihan fitness siswa-siswa putera SMA Negeri 3 Tondano mampu mengikuti pelatihan fitness dan mempraktikkannya dengan baik.

\section{PEMBAHASAN}

Hasil pelaksanaan pengabdian masyarakat ini menunjukkan keberhasilan yang perlu diapresiasi oleh pihak perguruan tinggi dan pihak sekolah karena memberi dampak yang baik untuk mengembangkan ilmu pengetahuan.

Program pelatihan merupakan salah satu strategi atau disaat dalam usaha mencapai suatu prestasi maksimal yang diharapkan oleh pelatih atau guru olahraga.Harsono (1988:101) menyatakan bahwa latihan adalah "Proses yang sistematis dari berlatih atau bekerja, yang dilakukan secara berulang-ulang dengan kian hari kian menambah jumlah beban latihan atau pekerjaannya". Jadi dapat disimpulkan bahwa program pelatihan merupakan suatu proses yang sistematis dan dilakukan secara berulang-ulang 
dengan penambahan beban secara teratur dan terprogram.

Dengan mengetahui syarat-syarat yang khas dari tiap cabang olahraga serta mengetahui kelemahan-kelemahan fisik dari olahragawan maka program pelatihan dapat dibuata untuk membawa atlet pada kondisi fisik yang prima.Dengan mengetahui kemampuan dan kelemahan komponen fisik dari masing masing atlet, maka pelatihpun dapat mengambil manfaat untuk mengambil keputusan-keputusan tertentu guna mencapai hasil maksimal yang diharapkan.Untuk mencapai prestasi prima seorang atlet diperlukan usaha dan daya berlatih-melatih yang dituangkan dalam rencana program pelatihan tertulis sebagai pedoman arah kegiatan untuk mencapai tujuan secara efektif dan efisien.

Bompa (1990:1-8) menyatakan bahwa : "Latihan adalah suatu aktivitas olahraga yang sistematis, dalam jangka waktu yang panjang, ditingkatkan secara bertahap dan individual, ditujukan pada fungsi fisiologis dan psikologis manusia untuk memenuhi tugas-tugas yang dibutuhkan."

Ngurah Nala (1998:41) menyatakan bahwa: "Agar atlet memperoleh penampilan yang optimal dalam olahraga tidaklah berarti yang dikembangkan hanya factor fisiknya saja, tetapi juga factor lainnya seperti faktor teknik Kemampuan fisik seorang atlet yang dituntut masing-masing cabang olahraga agar berprestasi dengan baik.
Fitness dituntut mempunyai kemampuan komponen fisik yang berbeda dengan seorang pengangkat besi, pesenam, atletik, peloncat gawang.Untuk mencapai tingkat kemampuan fisik tersebut membutuhkan pelatihan yang disiplin, sehingga perlu diperhatikan dan dievaluasi apakah program pelatihan, pelaksanaannya sudah efektif seperti yang dikehendaki. Junusul Hairy menatakan bahwa: "Setiap program pelatihan akan sangat efektif apabila secara rutin bertambahnya berat untuk setiap minggunya atau setiap dua minggu. Sebab tubuh akan selalu beradaptasi dengan keadaanya atau stress yang baru. Jadi kalau satu tingkatan program latihan telah dijalankan, tubuh tidak memerlukan waktu yang lama untuk melakukan adaptasi sehingga beban semula yang dirasa sangat berat akan terasa menjadi ringan. Dengan demikian bahwa latihan itu hendaknya dapat dilakukan secara sitematis berulangulang kian hari kian menambah jumlah beban latihan apabila beban sudah dapat dilakukan dengan mudah maka perlu ditingkatkan secara bertahap.

Hakikat Fitness

Fitness adalah kegiatan olahraga pembentukan otot-otot tubuh/fisik yang dilakukan secara rutin dan berkala, yang bertujuan untuk menjaga fitalitas tubuh dan berlatih disiplin. 
Manfaat Fitness bagi Kesehatan:

1.Pembakaran lemak

Olahraga akan membakar lemak.

Sekecil apapun waktu atau porsi pelatihan yang sedang dijalani. Tujuan ini seringkali menjadi prioritas utama bagi mereka yang ingin menurunkan berat badan. Alah satu contoh pelatihan mengangkat beban yang dilakukan tiga hari seminggu dalam waktu dua bulan setidaknya pembakaran lemak bisa mencapai 3,5 pounds.

2.Kekuatan fisik

Pelatihan dalam program fitness bukan sekedar ingin membentuk badan kekardan seksi.Tetapi lebih dari itu, anda akan mengalami perubahan besar dalam kekuatan fisik.Jumlah otot akan bertambah sesuai dengan porsi pelatihan sekaligus meningkatkan kemampuan anda dalam mengangkat beban. Dan anda bisa memilih untuk memilih tidak menjadi kekar karena ada program dengan regulasi tertentu sehingga bentuk badan tetap ideal,tetapi dengan kekuatan fisik yang lebih bagus.

3.Kebugaran

Menjalankan program fitness secara teratur akan meningkatkan kebugaran. Anda tidak akan mudah mengantuk dalam rutinitas sehari-hari.

4.Mengurangi Resiko Penyakit

Ada banyak ancaman penyakit yang bisa menyerang siapa saja,persoalan ini sering menjadi dilemma bagi mereka yang ingin berolahraga tapi merasa khawatir dengan resiko dan konsekwensi selama pelatihan.

\section{Detoksifikasi}

Selain untuk membentuk fisik dan kekuatan,program fitness yang dijalani secara teratur akan membantu proses detoksifikasi atau pengeluaran racun dari tubuh. Normalnya racun dalam tubuh dikeluarkan melalui beberapa proses alami seperti urine,ludah dan nafas.Program fitness akan membantu meninkatkan kualitas pernafasan sehingga kinerja ginjal akan semakin baik sekaligus melancarkan proses detoksifikasi.

6.Meningkatkan Metabolisme

Berlatih fitness akan membantu proses metabolism yang maksimal.Jadi anda tidak perlu khawatir jika banyak menyantap makanan berkalori selama menjalani olahraga secara teratur.

\section{Mencegah Stres}

Program fitness akan membantu mengurangi stress, atau menghilangkan resikonya. Akibat dari tekanan pekerjaan dan rutinitas keseharian, orang bisa saja mengalami stress dalam skala kecil, tetapi jika terus menerus ditumpuk menjadi beban pikiran hal itu akan berpengaruh pada kesehtan fisik.

8.Meningkatkan konsentrasi

Menurunnya daya konsentrasi dan ingatan dipengaruhi oleh umur yang bertambah.Tapi masalah tersebut bisa diatasi dengan menyeimbangkan pelatihan fisik dalam program fitness. 
9.Melawan pikun di hari tua

Jika anda rajin berolahraga di hari muda maka sudah seyogyanya anda tidak perlu khawatir dengan kepikunan di hari tua. Fitness merupakan salah satu latihan yang dapat menghilangkan pikun di hari tua.

10.Membentuk dan mempercantik tubuh Fitness bukan hanya untuk membentuk tubuh pria agar tampil kekar dan memiliki bentuk yang berotot-otot. Fitness memiliki banyak jenis yang tidak semuanya bertujuan untuk membentuk fisik,anda dapat mempercantik pinggul,lekukan tubuh baik untuk pria dan wanita agar tampil lebih menawan.

\section{Bersosial}

Anda memiliki waktu luang untuk fitness akan memiliki banyak teman dan tentu komunitas serta pergaulan yang sehat dan bugar. Dengan bergaul dengan teman yang ikut fitness maka sudah sewajarnya anda saling berbagi dan bertukar informasi mengenai kesehatan atau info gizi lainnya.

\section{Menikmati Hidup}

Fitness juga dapat digunakan sebagai hobi yang sangat menyenangkan, tidak heran ada banyak orang memanfaatkannya hanya sebagai menjalankan hobi yang menurutnya sangat menarik. Berkenalan dengan teman, berkumpul dan berbagi tips mungkin sangat menyenangkan bagi mereka yang menjalaninya.

\section{Melatih Pernafasan}

Sering dan rutin fitness merupakan salah satu cara untuk melatih pernafasan yang sangat dianjurkan oleh berbagai professional. Dengan rajin fitness anada akan memiliki pernafasan yang sangat prima.

\section{KESIMPULAN DAN SARAN}

Kesimpulan

Berdasarkan hasil pengabdian kepada masyarakat dan pembahasan yang telah dilakukan makadapat disimpulkan:

a. Pelatihan fitness dapat berjalan dengan baik,penuh semangat dan menghasilkan fisik yang bugar

b. Melalui pelatihan fitness ini maka semakin

tumbuh,sportifitas,semangat, kerjasama dan dapat meningkatkan keterampilan fitness.

c. Melalui pelatihan ini dapat meningkatkan pengetahuan

\section{Saran}

a. Kepada siswa-siswa SMA Negeri 3 Tondano dapat memotivasi teman siswa lainnya untuk dapat berlatih bersama-sama untuk meningkatkan fitness itu sendiri.

b. Diharapkan pelatihan fitness ini dapat dilaksanakan secara berkesinambungan sehingga semua siswa memperoleh kesempatan yang sama untuk mendapatkan 
pengetahuan dan keterampilan fitness.

c. Diharapkan kerjasama antara LPPM UNIMA antar sekolah-sekolah lain untuk dapat mengembangkan pengetahuan ini secara merata.

\section{KEPUSTAKAAN}

Imam Sodikun. Olahraga Pilihan Bola Basket, Depdikbud, Dirjen Pendidikan Tinggi, Proyek Pembinaan Tenaga Kependidikan, 1992.

Mohamad Sajoto. Pembinaan Kondisi Fisik Dalam Olahraga. Jakarta; Depdikbud, Dirjen Pendidikan Tinggi, PPLPTK, 1988.

Mziki90.blogspot.com/2016/10/Pengertian fitness dan manfaatnya,html. Diposting oleh Dycky Marine di 11.16. Ngurah Nala. Pelatihan Fisik Olahraga. Program Pascasarjana Program Studi Fisiologi Olahraga universitas Udayana.Denpasar 1998.

Sujudi Imam Permainan Dan Organisasi Pertandingan, Departemen Pendidikan Dan Kebudayaan Universitas Terbuka, Jakarta 1986. 
Jurnal ABDIMAS, Vol. 12, No. 3, Desember 2019

ISSN: 1979-0953 | e-ISSN: 2598-6066 